\title{
Regression between Headmaster Leadership, Task Load and Job Satisfaction of Special Education Integration Program Teacher
}

\author{
Mohd Norazmi bin Nordin*, Mohamad Zaid Bin Mustafa, Abdul Rasid Bin Abdul Razzaq \\ Department of Professional Education and Postgraduates, Faculty of Technical and Vocational Education, Universiti Tun Hussein \\ Onn Malaysia, Malaysia
}

Received December 2, 2019; Revised January 21, 2020; Accepted February 18, 2020

Copyright $\bigcirc 2020$ by authors, all rights reserved. Authors agree that this article remains permanently open access under the terms of the Creative Commons Attribution License 4.0 International License

\begin{abstract}
Managing school is a daunting task for a headmaster. This responsibility is exacerbated when it involves the Special Education Integration Program (SEIP). This situation requires appropriate and effective leadership in addressing some of the issues that are currently taking place at SEIP such as task load and job satisfaction. This study aimed to identify the influence of headmaster leadership on task load and teacher job satisfaction at SEIP. This quantitative study was conducted by distributing 400 sets of randomized questionnaires to SEIP teachers across Malaysia through google form. The data obtained were then analyzed using Structural Equation Modeling (SEM) and AMOS software. The results show that there is a significant positive effect on the leadership of the headmaster and the task load of the teacher. Likewise, the construct of task load and teacher job satisfaction has a significant positive effect. However, for the construct of headmaster leadership and teacher job satisfaction, there was no significant positive relationship. This finding is very important as a reference to the school administration re-evaluating their leadership so as not to burden SEIP teachers and to give them job satisfaction. In addition, the findings of this study can also serve as a guide for SEIP teachers to increase awareness of the importance of managing their tasks. This study also focused on education leadership in general and more specifically on special education leadership.
\end{abstract}

Keywords Headmaster Leadership, Task Load, Teacher Job Satisfaction, Special Education Integration Program

\section{Introduction}

There are five factors that contribute to the issue of high SEIP teachers' task load, namely, teachers, students, policies, facilities and leadership (John Anderson, 2017). The first factor is the teacher's inability to manage tasks, minimal knowledge and a lack of willingness to cooperate (Siri, 2017; A malina \& Azita, 2016; Norizan et al., 2013). The second factor is the incomplete and unsafe facility factor (Rosnah Ishak \& Siti Nur Fat ihah, 2018; Cambridge et al., 2014; Brian, 2014). The third factor is the special need student (SNS) factor of various categories of dis ability (John Anderson, 2017; Series, 2017; Junaidah \& Nik Rosila, 2013). The fourth factor is that the changing curriculum and policies are causing many special education teachers to do more work (A malina \& Azita, 2016; Cambridge et al., 2014; Erica \& Raymond, 2009). The fifth factor is the leadership factor of the headmaster in the school (Awang Lokey \& M. Hasani, 2016: Hanson Dawn, 2011; Sylvine \& Michele, 2011).

However, the most important factor in influencing the burden of high SEIP teachers' task load is that of headmasters' leadership because they are the individuals responsible for the overall operation of the school (John Anderson, 2017). Among the problems faced by head teachers that could increase the task load of teachers and thus interfere with teacher job satisfaction are their own attitudes as reported by Nelson et al. (2014) showed that headmasters do not provide the encouragement and support to perform large, burdensome tasks. The attitude of those who do not pay proper attention to special education and the notion that special education is the only passenger in the school raises the is sue of teachers' task load and the dissatisfaction of working special education teachers in SEIP endlessly (Erica \& Raymond, 2009). 


\section{Background Research}

In a preliminary interview with five SEIP teachers in Johor, it was found that leaders in a school with programs such as SEIP need to have sufficient knowledge of special education and demonstrate a fair attitude in dealing with teachers and students in school. They said that the headmasters of the school did not pay attention to SEIP and instead focused on the achievements of mainstream students. They also constantly burden teachers in the SEIP with a lot of outside work because their attitude towards the teachers is more so that the teachers do not have much work in the SEIP. Some of them said that headmasters always provide important work at the school level for teachers at SEIP because they lack knowledge of the extra task load that teachers face in managing SNS. They also stated that their headmaster was autocratic in delivering assignments, and all instructions given were coercive, without discretion and needed to be prepared in a short period.

Shawnee et al. (2006) in their study of school leaders' knowledge of special education and its impact on their implementation of special education programs in secondary schools in North Carolina, USA found a direct impact on the construct. They assert that school leaders who do not have sufficient knowledge of special education will implement poor leadership on special education programs. The same is true of John Anderson (2017), who argues that the major problem with teachers' job satisfaction issues is the lack of knowledge and experience of major teachers in special education. Their lack of care will make special education programs in schools less successful (Shawnee et al., 2006). Engaged special education teachers will also face obstacles in the performance of their assignments due to the lack of ongoing support and guidance from the school administration (Junaidah \& Nik Rusila, 2013).

a. Research objective

- To examine the regression between headmaster leadership, task load and SEIP teacher job satisfaction.

\section{b. Research questions}

- Is there a regression between headmaster leadership, task load and SEIP teacher job satisfaction?

\section{Literature Review}

Zakaria's (2016) study of headmaster leadership style and school effectiveness found that unrelated teacher tasks caused the teaching and learning process in the classroom to be disrupted, and this situation necessarily led to dissatisfaction with aspects of teacher work quality. In SEIP, students need to have teachers' full attention (Norashikin et al., 2015). They also point out that in leadership there is a need to be aware of a task in order to made a good change. Although this study is related to teacher leadership, the awareness needed to be higher for a school leader. Ahmad and Raziah (2009) view those headmasters should create a sense of satisfaction for teachers with carrying out their tasks. In the SEIP, for example, special education teachers dealing with SNS need to concentrate their energies as well as their efforts on ensuring that SNS are well-received and well-educated (Special Education Division, 2015).

As outlined in the Special Education Integration Program Operations Handbook by Ministry of Education, among the roles of headmasters in schools with SEIP are as follows, setting up a special education program integration committee and ensuring full functioning at the school level, ensuring all special education teachers implement SEIP with effectiveness, making the SEIP the years target, emphasizing that special education teachers implement the teaching process at their respective SEIP, conducting and monitoring of the teaching process of special education assistant/coordinator and special education teacher, ensuring the physical aspects of the classroom are safe and appropriate for the learning process, forging close working relationships between SNS's parents and the school, and providing periodic reports of SEIP achievement for Ministry of Education (Special Education Division, 2015). These guidelines clearly emphasize that special education teachers should pay particular attention to SNS and SEIP. However, most headmasters do not know and do not provide encouragement for special education teachers to carry out their tasks (Nelson et al., 2014). The problematic leadership of the headmasters will result in the burden of the SEIP teachers (Junaidah \& Nik Rusila, 2013). This will also result in the loss of job satisfaction of special education teachers (John Anderson, 2017).

Nelson et al. (2014) stated that special education teachers who are burdened with high duties are not satisfied with carrying out their core tasks of teaching SNS. They also point out that the inconsistency of special education teachers' vacations increases their job satisfaction. Amalina and Azita (2016) support this assertion that increasing levels of pressure on SEIP teachers in completing assignments have led to a lack of satisfaction in carrying out their assignments. Angela (2013) and Rabayah et al. (2010) on the other hand stated that SEIP teachers are physically unable to enjoy the satisfaction of working when no reward is given after the teachers have successfully completed the assignment.

Head masters who do not provide proper encouragement for SEIP teachers to perform the task also affect the job satisfaction of the teachers (Louise Strydom et al., 2012). Norizan et al. (2013) stated that the attitude of headmasters who do not understand the true role of SEIP teachers has led to the disruption of teachers' job satisfaction with teaching SNS. Similarly, Junaidah and Nik Rusila (2013) points out that those who understand the workings of SEIP teachers will adopt a leadership 
style that does not interfere with teacher satisfaction. Massithah (2009) states that teachers in SEIP are dissatisfied with their work because they are disturbed by the practice of headmasters and their negative attitude towards special education. Whereas Peggy Lau (2008) found that the satisfaction of special education teachers is influenced by their work relationships with peers and teachers.

The is sue of high tasks load on teachers in SEIP due to the leadership of headmasters has persisted for many years (John Anderson, 2017). This issue further affects the job satisfaction of teachers at SEIP (Junaidah \& Nik Rusila, 2013). This is evidenced by several state-based studies across Malaysia such as Junaidah and Nik Rosila (2013) in the state of Perlis, Awang Lokey and M. Hasani Dali (2016) in the state of Kedah, Ghani et al. (2015) in the state of Penang, Rabayah et al. (2010) in Perak, Habib and Zaimah (2012) in Selangor, Mohamad Abdillah Royo and Woo (2010) in Kuala Lumpur, Ahmad and Raziah (2009) in Negeri Sembilan, Norizan et al. (2013) in the state of Terengganu, quoted in the newspaper Sinar Harian by Sapinah Ab Ghani (2015) entitled "Special Offerings of Special Education Teachers in Kelantan", Mohd Nasir, Ruzanna and Suhaida (2013) in SMPKV throughout Malaysia including the Kuantan SMPKV in Pahang, and Norashid and Hamzah (2014) in the state of Sabah. For the state of Johor there are many studies that prove this, such as the case study by Abdul Rahim et al. (2006), Amalina and Azita (2016), and Johan (2013). In light of this issue, researchers have found it necessary to identify the influence of headmaster leadership on the task load and job satisfaction of SEIP teachers.

\section{Research Methodology}

This study used the full quantitative method in data collection. Researchers distributed randomized questionnaires sets of 119 items to SEIP teachers using google form. A total of 400 respondents answered the questionnaire completely and suitably for analysis. The data were then analy zed by Structural Equation Modelling (SEM) using AMOS 21. The test is performed by combining all three constructs in one structural model. Through these structural models, the regression between constructs can be identified. The main criterion for determining this compatibility is to look at the positive factor loading value that should be $\geq 0.50$ (Hair et al., 2010). For fitness index, the RMSEA value should be $\leq$ 0.08 (Byrne, 2001), while the GFI, CFI and TLI values should be $\geq 0.90$ (Bentler, 1990; Hatcher, 1994). Relative / Normed Chi-Square values must be approximately $\leq 5.0$ (Bentler, 1990). In order to verify the regression between constructs, Standardized Regression Weight must be taken into account (Fornell \& Larcker, 1981; Hair et al., 2010). In addition, significant values must be $<0.05$ to indicate acceptable values (Creswell, 2012).

\section{Findings}

Based on the findings of the study as summarized in Table 1, it can be stated that this model of structure achieves its match.

Table 1. Fit Indexes

\begin{tabular}{|c|c|}
\hline Fit Indexes & Value \\
\hline Relative Ci-Sq & 2.319 \\
\hline CFI/TLI & 0.903 \\
\hline RMSEA & 0.58 \\
\hline
\end{tabular}

The findings also show that when the headmasters' leadership construct increases 1 , the teacher task load construct increases by 0.892 . Whereas if the task load construct increased by 1 , the job satisfaction construct increased by 0.786 , and in the event of a 1 increase for the headmaster leadership construct, the job satisfaction construct increased by 0.122 , as shown in Table 2 .

Table 2. Standardized Regression Weight

\begin{tabular}{|c|c|c|c|}
\hline Constructs & $\begin{array}{c}\text { Standardized } \\
\text { Estimate }\end{array}$ & $\mathrm{p}$-value & Notes \\
\hline $\begin{array}{c}\text { Teachers Task Load } \\
\text { <---Headmasters } \\
\text { Leadership }\end{array}$ & 0.892 & 0.000 & Significant \\
\hline $\begin{array}{c}\text { Teachers Job Satisfaction } \\
\text { <--- Teachers Task Load }\end{array}$ & 0.786 & 0.000 & Significant \\
\hline $\begin{array}{c}\text { Headmasters Leadership } \\
\text { <---Teachers Job } \\
\text { Satisfaction }\end{array}$ & 0.122 & 0.140 & $\begin{array}{c}\text { Not } \\
\text { Significant }\end{array}$ \\
\hline
\end{tabular}

H1: The construct of the headmaster leadership has a significant positive impact on the construct of the teachers task load. The results of the Structural Equation Model analysis of the path coefficients between headmasters' leadership and teacher task load showed significant positive effects $(\beta=0.892, p=0.000, p<0.005)$. This indicates that there is a positive and significant direct effect on headmaster leadership and teacher task load.

$\mathrm{H} 2$ : The construct of the teachers task load has a significant positive impact on the cons truct of the teachers' job satisfaction. The results of the Structural Equation Model analysis of the coefficients of the path between teachers' task load and teachers' job satisfaction showed significant positive effects $(\beta=0.786, p=0.000, p<0.005)$. This indicates that there is a positive and significant direct effect on teachers' task load and teacher job satisfaction.

H3: The construct of the headmasters' leadership has a significant positive impact on the construct of teachers' job satisfaction. The results of the Structural Equation Model analysis of the coefficients of the path between headmasters' leadership and teachers' job satisfaction showed no significant positive effects $(\beta=0.122, p=0.140$, $\mathrm{p}>0.005)$. This indicates that there is a positive but not significant direct effect on headmasters' leadership and teachers' job satisfaction. 


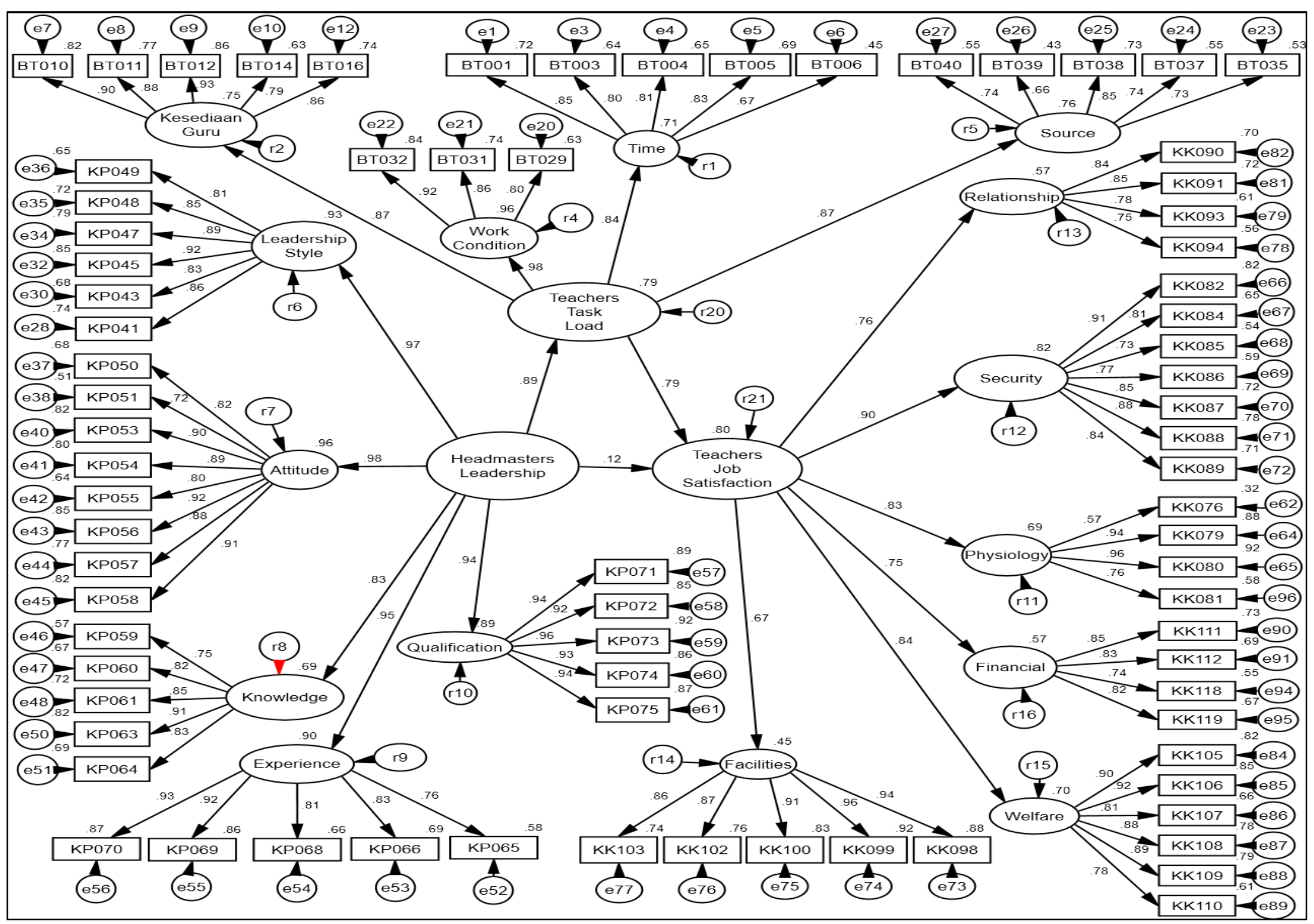

Figure 1. Research Structural Model 


\section{Discussion}

The findings show that there is a significant positive effect on the headmasters' leadership and the teachers' task load. This means that there is a positive and significant direct impact on the leadership of the headmasters with the teachers task load. This finding is in line with Abdul Rahim et al. (2006), who found that everything that a headmaster does in their leadership would put a teacher at a disadvantage over the task they were doing. The study also found that the leadership of headmasters is also a major factor in influencing the way their teachers work. This also supports the statement by Mustamin and Muzzammil (2013) that school principals need to be competent to carry out their heavy-duty as leaders for the welfare of teachers and the achievement of student.

The findings of this study are also consistent with the findings of a study by Junaidah and Nik Rusila (2013) who found that leadership factors are a major factor in determining teacher task load. In addition, the study by Rabayah et al. (2010) also explained that the high task load faced by SEIP teachers was the result of external assignments by school leaders. Similarly, the statement by Nelson et al. (2014) emphasized that the external task that burdened the SEIP teachers came from headmasters who practice leadership that is less suited to the special education environment.

The findings show that headmaster leadership has a positive effect on teacher job satisfaction but it is not significant. This indicates that there is a positive direct effect on headmaster leadership on teacher job satisfaction, but it is not significant. This situation occurs when the construct is incorporated into a model that has a mediator factor. This indicates that teachers' job satisfaction will be dis rupted by the leadership of the headmasters in the event of heavy task loads. If the tests were conducted directly between the headmaster and teacher job satisfaction without involving the mediator, the findings of the study would show significant positive effects between the two constructs in the model.

The findings of this study are in line with the study by Ahmad and Raziah (2009) who found that the leadership of headmaster affects the job satisfaction of special education teachers if tested directly. Also in the opinion of John Anderson (2017), Norashikin et al. (2015), Marquardt (2009) and Shawnee et al. (2006), they feel that the leadership of the headmaster is capable of contributing to the job satisfaction of special education teachers. Some researchers also stated that the practice of headmaster leadership would interfere with the achievement of teacher job satisfaction if they did not have sufficient knowledge of SEIP operations, such as John Anderson (2017), Baharuzaini et al. (2016), Adam (2014), Billingsley et al. (2014), Norizan et al. (2013) and Johan (2013).

The findings of this study found that there is a significant positive effect on teacher task load and teacher job satisfaction. This indicates that there is a direct and positive influence on teacher task load on teacher job satisfaction. This demonstrates that the high task load borne by SEIP teachers has an impact on their job satisfaction. The findings of this study are in line with the study by Muhammad Hisham, Jamalul Lail and Azlin Norhaini (2017), who stated that high task load will affect teachers' ability to work better. Muyan and Ramli (2017) also agree that the mastery of the leadership style in the school by the principals in delivering the tasks should enable SEIP teachers to perform their tasks with joy and satisfaction.

Junaidah and Nik Rosila (2013) also agree that the task load needs attention, which aims to maximize teachers' commitment to the task that ensures their job satisfaction. A study by Habib and Zaimah (2012) also found that teachers' task load and teacher job satisfaction were strongly correlated. Johan (2013) and Marquardt (2009) explain that the tasks and responsibilities that are assumed at one time effect the work environment and teacher's satisfaction. Similarly, John Anderson (2017) argues that the major problem of teachers' job satisfaction issues is the lack of knowledge and experience of headmasters in special education as well as high task load.

\section{Conclusions and Suggestion}

Overall, there were relationships and influences among the constructs in this study namely headmasters leadership, teacher task load and teacher job satisfaction. The model developed shows that the leadership of the headmaster influences the task load of teachers as well as the job satisfaction of SEIP teachers. The effect of headmasters leadership on teacher job satisfaction is due to the in fluence of teacher task load. All of the influences shown by the three constructs on each other are based on positive, significant and practical weight regression values. As a suggestion, it is proposed that this study be conducted qualitatively to obtain more research data.

\section{Acknowledgements}

The authors would like to thank Ministry of Education Malaysia for supporting this research under Fundamental Research Grant Scheme Vot No. K207, FGRS/1/2019/SS109/UTHM/02/1 and thank Universiti Tun Hussein Onn Malaysia for partially sponsoring the research.

\section{REFERENCE}

[1] Abdul Rahim Hamdan, Ahmad Johari Sihes, Jamaluddin 
Ramli, \& Musa Ismail (2006). Tahap Minat, Pengetahuan Dan Kemahiran, Latihan Guru Dan Beban Tugas Guru Program Pemulihan Khas Sekolah Kebangsaan Daerah Pontian, Johor. Annual Conference on Teacher Education, 6-8 Sept 2006, Kota Kinabalu, Sabah.pp 18-23.

[2] Adam C. Garand (2014). Perceptions of Leadership through the Lens of Special Education Administrators and Principals. University of Massachusetts: Doctoral Dissertations.

[3] Ahmad Esa \& Raziah Mansor (2009). Hubungan Gaya Kepimpinan Guru Besar Dengan Kepuasan Kerja Guru Di Tiga Buah Sekolah Rendah Di Seremban. Seminar Kebangsaan Pengurusan Pendidikan (PKPGB2009), 7 Mei 2009, Universiti Tun Hussein Onn Malay sia.

[4] Amalina Binti Razali \& Azita binti Ali (2016). Faktor-Faktor Yang Mempengaruhi Tahap Stres Guru Pendidikan Khas. Active Online Journal, UTHM, 8, 1.

[5] Angela Bost Duncan (2010). Principal Leadership for Special Education: Perceptions of Principals and Directors of Special Education. Directed by Dr. Carl Lashley. 200 pp.

[6] Awang Lokey \& M. Hasani Dali (2016). Hubungan Antara Kepimpinan Transformasional Guru Besar Dengan Komitmen Guru Pendidikan Khas Integrasi Di Kedah. Jurnal Kepimpinan Pendidikan, Januari 2016, Bil. 3(1): 14-28.

[7] Baharuzaini Baharin, Muhammad Hisham Adnan, Mohd Hanif Mohd Zin, Mohd Norhisyam Kamaludin \& Azlin Norhaini Mansor (2016). Gaya Kepimpinan Guru Besar Dan Tahap Efikasi Guru. Journal of Personalized Learning, 2(1) 2016: 9-17.

[8] Bentler, P. M. (1990). Comparative Fit Indexes in Structural Models. Psychological Bulletin, 107(2), 238-246.http://dx.doi.org/10.1037/0033-2909.107.2.238

[9] Billingsley, B., McLeskey, J., \& Crockett, J. B. (2014). Principal Leadership: Moving Toward Inclusive and High-Achieving Schools for Students with Disabilities. Retrieved at 17 October 2018, fromhttp://ceedar.education.ufl.edu/tools/innovation-confi gurations/

[10] Brian Joseph Inglesby (2014). Principals Utilizing Leadership for Special Education: The Pulse Workshop Model for Improving the Practice of Instructional Leadership For Special Education. Retrieved at 18 October 2018, from https://gse.berkeley.edu

[11] Byrne, B. M. (2010). Multivariate Application Series. Structural Equation Modeling with AMOS: Basic Concepts, Applications, and Programming (2nd edition). New York, US: Routledge/Taylor \& Francis Group.

[12] Cambridge-Johnson, J., Hunter-Johnson, Y., \& Newton, N. G. (2014). Breaking the Silence of Mainstream Teachers' Attitude towards Inclusive Education in the Bahamas: High School Teachers' Perceptions. The Qualitative Report, 19(42):1-20.

[13] Creswell, John W. (2012). Educational Research: Planning, Conducting and Evaluating Quantitative and Qualitative Research. 4th Edition. USA: Pearson Education Inc.

[14] Erica Nance, Raymond L. Calabrese (2009). Special
Education Teacher Retention and Attrition: The Impact Of Increased Legal Requirements. International Journal of Educational Management, Vol. 23 Issue: 5, pp.431-440.

[15] Fornell, C. D., \& Lacker, D. F. (1981). Evaluating Structural Equation models with Unobservable Variables and Measurement Error. Journal of Marketing Research, 18, 39-50. http://dx.doi.org/10.2307/3151312

[16] Ghani, Mohd Zuri \& Chandramogan A/L Ramaiah, \& Thatchay ani A/P Santreseker (2015). Tahap Minat, Keyakinan, Kemahiran dan Beban Tugas Guru Program Pendidikan Khas Integrasi Masalah Pembelajaran Sekolah-sekolah Rendah Keban gsaan Negeri Pulau Pinang. Retrieved at 14 November 2018, from https://www.researc hgate.net/publication/29951026

[17] Hair, J. F., Black, W. C., Babin B. J., \& Anderson, R. E. (2010). Multivariate Data Analysis (7th Ed). Englewood Cliffs: Prentice Hall.

[18] Habib Ismail \& Zaimah Ramli (2012). Amalan Kepimpinan Transformasi Pengetua dan Hubungannya Dengan Kepuasan Kerja Guru. Prosiding Persidangan Kebangsaan Ekonomi Malaysia ke VII (PERKEM VII) Transformasi Ekonomi dan Sosial Ke Arah Negara Maju Ipoh, Perak, 4 6 Jun 2012,JILID 2 (2012): 1471 - 1478.

[19] Hanson Dawn M. (2011). Special Education Teacher Support \& Administrative Support of Special Education Teachers. Retrieved at 19 October 2018, from https://www .nmu.edu

[20] Hatcher, L. (1994) A Step-by-Step Approach to Using the SAS System for Factor Analysis and Structural Equation Modeling. SAS Institute, Inc., Cary.

[21] Johan Mohd Yaskom (2013). Analisis Keperluan Latihan Guru Penolong Kanan Pendidikan Khas. Universiti Teknologi Malaysia: Master Thesis.

[22] John Anderson (2017). A Workload Analysis Formula to Increase the Retention of Special Education Teachers in Minnesota. Culminating Projects in Special Education. 37.

[23] Junaidah Mohamad \& Nik Rosila Nik Yaacob (2013). Kajian Tentang Kepuasan Bekerja Dalam Kalangan Guru-Guru Pendidikan Khas. Asia Pacific Journal of Educators and Education, Vol. 28:103-115.

[24] Louise Strydom, Nico Nortjé, Roelf Beukes, Karel Esterhuyse and Jeanne van der Westhuizen (2011). Job Satisfaction amongst Teachers at Special Needs Schools. South African Journal of Education Vol 32: 255-266.

[25] Massithah (2009). Hubungan Pengajaran Guru Besar Dengan Komitmen Kerja Guru Di Sekolah Rendah Luar Bandar. The International Journal of Learning.Volume 16:21-29.

[26] Mohamad Abdillah Royo \& Woo Sew Fun (2010) Faktor-Faktor Yang Mendorong Tekanan Kerja (Stres) Di Kalangan Guru-Guru Sjk(C): Satu Kajian Di Tiga Buah Sekolah Di Wilayah Persekutuan. pp. 1-12.

[27] Mohd Nasir, Ruzanna \& Suhaida Abdul Kadir. (2013). Beban tugas guru teknikal di Sekolah Menengah Pendidikan Khas Vokasional (SMPKV). Graduate Research in Education Seminar (GREduc 2013), 1 Dec. 2013, Faculty of Educational Studies, Universiti Putra 
Malaysia. (pp. 466-469).

[28] Muhammad Hisham, Jamalul Lail \& Azlin Norhaini (2017). Tahap Kepuasan Kerja Guru: Aspek Beban Kerja, Pengiktirafan dan Penglibatan Dalam Pengurusan. Jurnal Penyelidikan Pendidikan Jilid 18 (2017): 187-199.

[29] Mustamin \& Muzzammil Hj. Mohd. Yasin. (2013). Perbandingan Kompetensi Pengetua Sekolah antara Malaysia dan Indonesia. Jurnal Teknologi (Social Sciences) 62:1 (2013): 7-16.

[30] Muy an \& Ramli. (2017). Hubungan Gaya Kepimpinan Guru Besar Dan Motivasi Guru Sekolah Rendah Di Daerah Bau, Sarawak. Jurnal Penyelidikan Pendidikan Jilid 18 (2017): 200-212.

[31] Nelson C. Brunsting, Melissa A. Sreckovic \& Kathleen Lynne Lane (2014). Special Education Teacher Burnout: A Synthesis of Research from 1979 to 201. Education and Treatment of Children, Volume 37, Number 4, November 2014, pp.681-711.

[32] Norashikin Abu Bakar, Ramli Basri \& Foo Say Fooi (2015) Hubungan Kepimpinan Guru dengan Pencapaian Akademik Pelajar. International Journal of Education and Training (InjET) 1(2) November: 1-11.

[33] Norizan Abdul Ghani, Zahidah Anisah Mohamad \& Che Wan Takwa Che Wan Abu Bakar (2013). Teachers' Challenges in Educating Special Children in Special Classes of Three Selected Primary Schools, Kuala Terengganu, Terengganu, Malaysia. Advances in Natural and Applied Sciences, 7(3): 284-291, 2013.

[34] Norashid Bin Othman \& Hamzah Bin Md Omar (2014). Beban Tugas Dan Motivasi Pengajaran Guru Di Sekolah Menengah Daerah Ranau. Journal for Educational Thinkers Vol. 5, pp. 35-57.

[35] Rabayah Yahaya, Mohd Zuri Ghani, Rahimi Che Aman, Aznan Che Ahmad, Zainud in Mohd Isa, Hairu lnizam Ismail \& Aswati Hamzah, (2010). Stress Dalam Kalangan Guru Pendidikan Khas. Jurnal MEDC Volume 6 2010: 1-11.

[36] Rosnah Ishak \& Siti Nur Fatihah Rusman (2018). Prestasi Kerja Guru Dan Hubunganny a Dengan Faktor Beban Tugas, Persekitaran Kerja Dan Personal: Kajian Kes Di Sebuah Sekolah Di Sabah. Jurnal Kepimpinan Pendidikan. Januari 2018, Bil. 5, Isu 1:60-71.

[37] Sapinah Ab Ghani (2015). Pengorbanan Guru Pendidikan Khas. Retrieved at 12 November 2018, from http://www.si narharian.com.my/semasa/pengorban an-guru-pendidikan-k has- 1.350927

[38] Siri Marie Olson (2017). Special Education Teacher Retention in Small Schools. Dissertation, Georgia State University. Retrieved at 18 October 2018, from https://sch olarworks.gsu.edu/ece_diss $/ 35$

[39] Shawnee, Browder, Diane Flowers \& Ahlgrim-Delzell, Lynn. (2006). Principals' Knowled ge of Fundamental and Current Issues in Special Education. NASSP Bulletin. 90 153-174.

[40] Special Education Division (2015). Buku Panduan Pengoperasian Program Pendidikan Khas Integrasi (PPKI). Retrieved at 10 November 2018, from www.moe.gov.my

[41] Sylvine Schmidt \& Michèle Venet (2012). Principals Facing
Inclusive Schooling or Integration. Canadian Journal of Education 35, 1 (2012): 217-238.

[42] Zakaria Othman (2016). Kepimpinan Instruksional Guru Besar Di Sekolah Kurang Murid. Retrieved at 27 November 2018, from studentsrepo.um.edu.my/6763/1 